\title{
Embaixadas originais: diplomacia, jornalismo e as relaçóes Argentina-Brasil (1888-1935)
}

\author{
João Paulo Coelho de Souza Rodrigues* \\ Universidade Federal de São João del-Rei, São João del-Rei, Minas Gerais, Brasil
}

\section{RESUMO}

$\mathrm{O}$ artigo analisa as visitas de jornalistas brasileiros a Buenos Aires e de jornalistas argentinos ao Rio de Janeiro, nas quais alguns exerceram o papel de mediadores culturais. Estas visitas reforçaram uma sociabilidade burguesa transnacional e foram apresentadas pela imprensa como um movimento de aproximação entre Argentina e Brasil, constituindo-se no que se pode chamar de uma diplomacia cultural informal.

Palavras-chave: rede cultural; diplomacia cultural; imprensa; sociabilidade.

\section{RESUMEN}

El artículo analiza las visitas de periodistas brasileños a Buenos Aires y de reporteros argentinos a Río de Janeiro, en las cuales algunos ejercieron un papel de mediadores culturales. Esas visitas reforzaron una sociabilidad burguesa transnacional y fueron presentadas por la prensa como un movimiento de aproximación entre Argentina y Brasil, convirtiéndose en lo que podría llamarse como una diplomacia cultural informal.

Palabras clave: red cultural; diplomacia cultural; prensa; sociabilidad.

\section{ABSTRACT}

The article analyses the cultural network created by the visits of Brazilian journalists to Buenos Aires and Argentinian journalists to Rio de Janeiro, in which some have acted as cultural mediators. Such visits reinforced a transnational bourgeois sociability, and were presented by the press as a movement of rapprochement between the two nations, in what could be defined as an informal cultural diplomacy.

Keywords: cultural network; cultural diplomacy; press; sociability.

DOI - http://dx.doi.org/10.1590/2237-101X01803605

Artigo recebido em 7 de novembro de 2016 e aprovado para a publicação em 6 de junho de 2017.

* Professor da Universidade Federal de São João del-Rei. E-mail: jprodrigues@ufsj.edu.br.

O autor agradece a Ori Preuss, Fernando Degiovanni, Danilo Ferretti, Luiz Francisco de Miranda e Lila

Caimari pelo debate de versôes prévias deste artigo. 
Em 5 de julho de 1888 desembarcaram em Buenos Aires Manuel Veloso Paranhos Pederneiras, Demerval da Fonseca e Fernando Mendes, correspondentes, respectivamente, do Jornal do Comércio, da Gazeta de Notícias e do Diário de Notícias. Durante 17 dias, Pederneiras, Fonseca e Mendes receberam uma calorosa acolhida, na forma de passeios, banquetes, recepçôes e idas a teatros, organizada por colegas da imprensa portenha. Não era a primeira vez que jornalistas brasileiros aportavam à "Rainha do Prata". Todavia, aquela viagem representaria uma importante mudança nas relaçôes entre Argentina e Brasil, pois o interesse da imprensa pelo fato era inédito e - o que ressaltava o ineditismo deste interesse - os três eram figuras de menor importância no jornalismo carioca.

Ao longo do século XIX a travessia entre Buenos Aires e Rio de Janeiro havia seguido de perto os ritmos da política. Até a década de 1880 isso significou que o fluxo se deu no sentido desta cidade em detrimento daquela. $\mathrm{Na}$ época das lutas independentistas, o Rio de Janeiro foi o que Ricardo Piccirilli denominou de "Meca dos refugiados (...) da política argentina". ${ }^{1}$ Nas décadas de 1830 e 1840, foi a vez de membros da chamada "geraçấo de 37" (Juan Bautista Alberdi, Domingo Faustino Sarmiento, José Mármol, Juan María Gutiérrez, Juana Manso, entre outros) passarem temporadas mais ou menos longas na Corte, o que resultou em uma pequena literatura de viagem sobre o Brasil e na inserçáo de alguns exilados na imprensa carioca. ${ }^{2}$ Mas os intelectuais brasileiros não viajavam ao Prata. Uma tímida inflexão iniciou-se a partir de 1870 com a visita do republicano Quintino Bocaiúva. Em 1882 foi a vez do cafeicultor paulista Eduardo Prado, e em 1889 do líder abolicionista Joaquim Nabuco. ${ }^{3}$ Todos eram também, note-se, jornalistas.

Em comum, essas viagens revelam uma movimentação assistemática e individualizada, com pouco suporte institucional ou cobertura da imprensa. A presença, em 1888, do trio brasileiro na capital argentina representou o início de uma série de transformações que iriam da cobertura dedicada pela imprensa até a organização das viagens, passando pelo perfil dos viajantes. As viagens passaram a ser matéria de informação e os jornalistas a ser representantes de suas naçôes. Torna-se possível, portanto, abordar o fenômeno da viagem intelectual entre Argentina e Brasil sob um novo prisma, na medida em que o intenso fluxo de jornalistas entre os dois países criou não somente uma rede de trocas culturais, mas também teceu uma nova relação com suas política externas. Uma vez que os jornalistas se portavam como representantes nacionais e emulavam a etiqueta diplomática, pode-se entender tal rede como

${ }^{1}$ PICCIRILLI, Ricardo. Argentinos en Rio de Janeiro: diplomacia, monarquía, independencia. Buenos Aires: Pleamar, 1969, p. 16.

${ }^{2}$ AMANTE, Adriana. Poéticas y políticas del destierro: argentinos en Brasil en la época de Rosas. Buenos Aires: Fondo de Cultura Económica, 2010.

${ }^{3}$ PREUSS, Ori. Transnational South America: experiences, ideas, and identities, 1860s-1900s. Londres e Nova York: Routledge, 2016, p. 57-73. 
João Paulo Coelho de Souza Rodrigues

conformando uma diplomacia cultural informal, ${ }^{4}$ através da qual alguns homens de imprensa exerceram o papel de mediadores culturais internacionais com a missão de aproximar os dois países.

O exame das viagens de jornalistas na conexão Rio-Buenos Aires reforça, por um lado, a dimensão transnacional que em anos recentes vem sendo valorizada pelas histórias social e cultural, na qual o espaço regional (que inclui em menor medida o Uruguai e o Paraguai) se configura através de trocas culturais que caminham de mãos dadas com o trânsito de indivíduos. ${ }^{5}$ Por outro lado, reforça a tendência a "desinsularizar" a análise da intelectualidade brasileira. ${ }^{6}$ Também incorpora uma nova categoria aos "viajantes culturais" (cientistas, artistas e intelectuais) aos quais recentemente se tem dado maior atençâo. ${ }^{7}$ Por fim, agrega novos elementos à história das redes culturais na América Latina. ${ }^{8}$

${ }^{4}$ Criticando a abordagem que define a diplomacia cultural como parte da política oficial exterior de um
Estado, na qual ressaltam as doutrinas, os textos e a estrutura burocrática desta diplomacia, Gienow-Hecht
propóe que "em vez de se concentrar na política - 'o que foi feito e com que propósito' - devemos expandir
nossa análise de 'quem fez e como o fez." Esta alteração permite alargar o conceito de diplomacia cultural,
o qual pode ser entendido como o esforço (formal, informal ou encoberto) para criar uma ligação cultural
entre povos de naçóes diferentes. Portanto, a diplomacia cultural não precisa depender exclusivamente de
agentes oficiais e pode incluir redes informais que não obedecem exclusivamente a diretrizes estatais. Ver:
GIENOW-HECHT, Jessica C. E. The anomaly of the cold War: cultural diplomacy and civil society since
1850. In: OSGOOD, Kenneth A.; ETHERIDGE, Brian C. (Org.). The United States and public diplomacy:
new directions in cultural and international history. Leiden; Boston: Martinus Nijhoff, 2010, p. 31-32. Para
uma análise da imprensa como agente de diplomacia cultural, ver da mesma autora: Transmission impossible:
American journalism as cultural diplomacy in postwar Germany, 1945-1955. Baton Rouge: Louisiana State University Press, 1999.

${ }_{5}^{5}$ AMANTE, Adriana. Poéticas y políticas del destierro: argentinos en Brasil en la época de Rosas, op. cit.; OLIVEIRA, Vítor Wagner Neto de. Nas águas do Prata: os trabalhadores da rota fluvial entre Buenos Aires e Corumbá (1910-1930). Campinas: Editora da Unicamp/Cecult, 2009; SCHETTINI, Cristiana. Exploração, gênero e circuitos sul-americanos nos processos de expulsão de estrangeiros (1907-1920). Tempo, Rio de Janeiro, v. 16, n. 33, p. 51-73, jul./dez. 2012; GALEANO, Diego. Criminosos viajantes: circulações transnacionais entre Rio de Janeiro e Buenos Aires (1890-1930). Rio de Janeiro: Arquivo Nacional, 2016; PREUSS, Ori. Transnational South America: experiences, ideas, and identities, 1860s-1900s, op. cit.

${ }^{6}$ A metáfora do Brasil como ilha isolada da América do Sul é analisada e contestada por PREUSS, Ori. Bridging the island: Brazilians'views of Spanish America and themselves, 1865-1912. Frankfurt e Madri: Iberoamericana-Vervuert, 2011. Outros autores que apontam para relações intensas entre a intelectualidade brasileira e latino-americana são: CASTRO, Fernando Vale. Pensando um continente: a Revista Americana e a criação de um projeto cultural para a América do Sul. Rio de Janeiro: Mauad/Faperj, 2012; e BAGGIO, Kátia Gerab. Ronald de Carvalho e Toda a América: diplomacia, ensaísmo, poesia e impressóes de viagem na sociabilidade intelectual entre o Brasil e a Hispano-América. In: BEIRED, José Luis Bendicho; CAPELATO, Maria Helena; PRADO, Maria Ligia Coelho (Org.). Intercâmbios políticos e mediaçôes culturais nas Américas. Assis/São Paulo: FCL-Assis-Unesp Publicações/Laboratório de Estudos de História das Américas — FFLCH - USP, 2010, p. 193-206.

${ }^{7}$ BRUNO, Paula (Org.). Visitas culturales en la Argentina, 1898-1936. Buenos Aires: Biblos, 2014.

${ }^{8}$ JOBIM, José Luís (Org.). Trocas e transferências culturais; escritores e intelectuais nas Américas. Niterói/Rio de Janeiro: Eduff/De Letras, 2008; BRAVO, Alvaro Fernández; MAIZ, Claudio (Org.). Episodios en la formación de redes culturales en América Latina. Buenos Aires: Prometeo, 2009; GONZÁLEZ, Alejandra Pita. La Unión Latino Americana y el boletín Renovación: redes intelectuales y revistas culturales en la década de 1920. Cidade do México: El Colegio de México/Universidad de Colima, 2009; SILVA, Ana Paula B. R. Diálogos sobre a escrita da história: Brasil e Argentina (1910-1940). Brasília: Fundação Alexandre de Gusmão, 2011. 
Uma primeira aproximação à conformação da dinâmica das relaçôes estabelecidas no circuito cultural Buenos Aires-Rio de Janeiro, no que diz respeito à forma como tal circuito foi elaborado e se tornou matéria de discurso, exige que se tenha um panorama dos personagens envolvidos, suas filiaçôes ou vínculos na imprensa, os formatos mais gerais das viagens e os momentos em que elas se deram, em uma espécie de tipologia do itinerário jornalístico.

\section{Tipos de viagens}

Em meio à euforia da assinatura da Lei Áurea, os leitores dos jornais cariocas receberam a notícia de que em Buenos Aires ocorreria uma grande manifestação pública em honra ao Brasil, organizada por Bartolomé Mitre (diretor do La Nación) em nome dos diários da capital e contando com a ajuda do governo do presidente Juárez Celman, o qual decretou feriado no dia 17 de maio. No dia 25 daquele mês, aniversário da Revoluçáo de 1810, que marca o início do processo emancipatório platino, O País, a Revista Ilustrada, a Cidade do Rio, o Diário de Notícias e a Gazeta de Notícias publicaram saudaçôes à data patriótica argentina. 'Também organizaram a ida de Pederneiras, Fonseca e Mendes, com o intuito de agradecerem pessoalmente à imprensa portenha.

A partir de entáo as viagens se tornaram mais costumeiras (Fonseca e Mendes, por exemplo, voltariam em outra comitiva, em 1913). É importante esmiuçar a lista de jornalistas e de viagens, pois isto permite uma primeira aproximação a alguns elementos importantes: os veículos de imprensa mais interessados ou financeiramente capazes de estreitar laços internacionais, os jornalistas que exerceram a função de mediadores culturais, o impacto contínuo dessas viagens entre a comunidade mais ampla de jornalistas, e as transformaçóes nos motivos das viagens. Ao se proceder dessa forma, nota-se que há diferentes tipos de viagens, nas quais há uma correlação entre o número de viajantes e a conformação de uma diplomacia cultural informal.

A lista de viajantes solitários ou em pequenos grupos é extensa. Visitaram Buenos Aires: Pardal Mallet (Gazeta de Notícias), em agosto de 1890; Joaquim Nabuco (Jornal do Brasil), em agosto de 1891; Tomás Lopes (Kosmos), em fevereiro de 1908; Oscar de Carvalho Azevedo (Agência Americana), em junho de 1914; João do Rio/Paulo Barreto (Atlântida), em abril de 1915; Julia Lopes de Almeida (O País), entre outubro e novembro de 1922; Mário Figueiredo Pimentel (Gazeta de Notícias), em abril de 1935. Visitaram o Rio de Janeiro: Felipe J. Moreira (El Censor), entre novembro e dezembro de 1889; Manuel Bernárdez (El Diario), em outubro de 1907 e entre junho e novembro de 1908; Ignacio Orzali (La Nación), em junho de 1914 e em outubro de 1920; Luis Mitre ( $L a N a-$

\footnotetext{
${ }^{9}$ PREUSS, Ori. Bridging the island: Brazilians'views of Spanish America and themselves, 1865-1912, op. cit., p. 47-61.
} 
ción), em agosto de 1910; Manuel Láinez (El Diario), em novembro de 1912; José Gallo (La Prensa) e José A. Cortejarena (La Razón), em outubro de 1920; Lorenzo Stanchina e Nicolás Olivari (Fray Mocho, Martín Fierro e Crítica), em janeiro de 1925; José Guaratino (La Argentina), Aristeo Salgueiro e Enrique Raul Fox (El Plata) em abril de 1926; Antonio Cuneo (Associated Press), em julho de 1926; Nicolás Olivari e Enrique González Tuñon (Crítica), em fevereiro de 1929; Roberto Arlt (El Mundo), entre março e maio de 1930; Victor Ortiz Machado (La Razón), em abril de 1930; Adam Spinelli, Enrique Rodriguez Larreta e Raul González Tuñón (Crítica), assim como Pedro Juan Vignale (El Mundo), em dezembro de 1930; Antonio Ferro e Ernesto Rosasco (Momento Político), em março de 1935, assim como Jaime Botana (Crítica), no mês seguinte.

A presença de jornalistas brasileiros em Buenos Aires e argentinos no Rio de Janeiro, em caráter individual ou em grupos pequenos, obedeceu aos mais variados critérios e envolveu renomados intelectuais e políticos (Nabuco, Láinez, Larreta), escritores famosos (Joáo do Rio e Julia Lopes de Almeida), de menor expressão (Tomás Lopes), ou de vanguarda (Arlt, Stanchina, Olivari e os irmãos Tunon), jornalistas experientes (Mallet, Bernárdez) ou sem renome (Guarantino, Fox). Alguns viajaram mais de uma vez (Olivari, Orzali, Spinelli). Geralmente representavam um grande diário das duas capitais (La Nación, Gazeta de Notícias, Crítica, La Prensa). Entre os visitantes havia não poucas vezes diretores (Orzali, Botana) e proprietários (Mitre, Láinez), mas pode-se encontrar também empregados de grandes agências de notícias internacionais (Cuneo). Podiam ir investigar a situação política local (Mallet, Nabuco) ou podiam apenas fazer uma escala de uma viagem à Europa (Mitre, Orzali, Botana, Láinez). No seu conjunto, essas viagens deram corpo a um constante ir e vir de jornalistas que alimentou um circuito de relaçôes e de rituais, bem como um discurso sobre as visitas, que serão analisados mais adiante.

Outros dois tipos de viagens se destacaram no noticiário: as comitivas que acompanharam visitas de Estado, oficiais e semioficiais, e os grupos de jornalistas mobilizados para cobrirem as inauguraçóes de transatlânticos e de linhas aéreas. No primeiro caso temos as viagens presidenciais de Julio Roca (agosto de 1899) e Agustín P. Justo (outubro de 1933) ao Brasil, e de Campos Sales (outubro de 1900) e Getúlio Vargas (maio-junho de 1935) à Argentina; as Conferências Pan-americanas do Rio de Janeiro (julho-agosto de 1906) e de Buenos Aires (julho-agosto de 1910); as passagens do ex-presidente Roca (março de 1907) e do presidente eleito Roque Sáenz Peńa (agosto de 1910) pela capital brasileira; a embaixada de Rui Barbosa às comemorações do centenário da declaração de independência argentina (julho de 1916). No segundo caso, temos as viagens inaugurais dos transatlânticos "Lutetia" (dezembro de 1913) e "Atlantique" (outubro de 1931), da Compagnie de Navigation Sud-Atlantique, e "Giulio Cesare" (maio-junho de 1922) e "Saturnia" (outubro a dezembro de 1927), da companhia Italia di Navigazione; finalmente, em abril de 1930, dos primeiros voos da New York, Rio and Buenos Aires Line e da Aeropostale. 
No seu conjunto, viajaram por volta de cinquenta jornalistas brasileiros e setenta argentinos, representando toda a grande imprensa das duas capitais, e, ocasionalmente, jornais provinciais. Somando-se os enviados especiais e os componentes das comitivas, os jornais cariocas com maior presença em Buenos Aires foram Jornal do Comércio, Gazeta de Notícias e $\mathrm{O}$ Pais. Nas mesmas condições, os jornais portenhos mais presentes no Rio foram $\mathrm{La} \mathrm{Na}$ ción, El País, La Prensa, Crítica, La Razón e El Diario. Também é de se notar que os semanários ilustrados de variedades, que adquirem grande popularidade entre 1900 e 1910, como Caras y Caretas, P.B.T., Fon-Fon e Careta enviariam, em algumas das ocasióes mencionadas, correspondentes. ${ }^{10}$

Este panorama das comitivas permite perceber o trânsito de certos jornalistas em particular, alguns dos quais, como se verá mais adiante, exerceram importante função nos laços criados entre a imprensa argentina e a brasileira, assim como no discurso que buscou dar sentido a esses laços. Vários viajaram mais de uma vez ao país vizinho, como Modesto San Juan, do semanário P.B.T., que esteve no Rio nas comitivas de 1906 e 1910, assim como Adam Spinelli, o qual já se detivera, como visto acima, na cidade em 1930 e 1931, e voltaria a ela dois anos depois, durante a visita presidencial do General Justo. São também os casos de Manuel Mujica Linares, do La Prensa, que acompanhou a $3^{\text {a }}$ Conferência e a passagem de Sáens Peña, e de Luís Edmundo, que esteve nas viagens inaugurais do "Lutetia" e do "Atlantique". Eles se juntam a outros que viajaram mais de uma vez de forma individual, como visto acima. E aos que mesmo tendo feito o percurso apenas uma vez, como Paulo Barreto e Julia Lopes de Almeida, proferiram conferências e concederam entrevistas sobre o Brasil em Buenos Aires e sobre a Argentina no Rio de Janeiro, além de doarem livros a bibliotecas da cidade visitada.

Mas os que mais se destacaram foram Ignacio Orzali e Olavo Bilac. Orzali esteve presente na viagem de Roca em 1899 como representante de La Voz de la Iglesia. Voltou mais quatro vezes (1906, 1910, 1914 e 1920), enquanto ascendia na redação do La Nación. Bilac acompanhou a visita de Campos Sales em 1900 representando a Gazeta de Notícias, e participou da $4^{a}$ Conferência Pan-Americana de 1910 como membro da comitiva diplomática brasileira. Ambos adquiriram relativa fama na imprensa da cidade que visitaram. Orzali,

\footnotetext{
${ }^{10}$ As viagens foram noticiadas ou comentadas na grande imprensa diária e em várias revistas semanais de variedades listadas no item "Fontes documentais" ao final do artigo, nos meses indicados acima. Os jornais cariocas e paulistas foram acessados em variadas ocasióes em: <http://bndigital.bn.gov.br/hemeroteca-digital/>. É possível encontrar todos os nomes citados acima através da ferramenta de busca do site. Os diários portenhos e as revistas Don Quijote e P.B.T. foram consultados na Hemeroteca da Biblioteca Nacional Mariano Moreno de Buenos Aires e na Hemeroteca do Congreso de la Nación. A revista Renascença foi consultada na biblioteca da Fundação Casa de Rui Barbosa (Rio de Janeiro). A revista Caras y Caretas está disponível na hemeroteca digital da Biblioteca Nacional da Espanha, em: <http://hemerotecadigital.bne.es/details.vm?q=id:0004080157\&lang=en>. Há também a identificação de jornalistas em livros que relatam ou comemoram estas viagens mencionados ao longo deste artigo. Nestas fontes aparecem alguns outros nomes, omitidos aqui seja porque as condiçôes de leitura, seja porque as discrepâncias na grafia entre diferentes periódicos impossibilitam uma identificação precisa.
} 
como se verá mais adiante, era regularmente entrevistado pelos jornais cariocas. Já Bilac teve alguns sonetos, bilhetes, cartas e retratos seus publicados por prestigiadas revistas de variedades portenhas. ${ }^{11}$

O trânsito do poeta parnasiano do jornalismo para a diplomacia revela ainda algumas das pontes construídas por esses dois campos no início do século XX, tanto no Brasil quanto na Argentina - o que ocorreu, em boa medida, justamente por causa das relaçôes entre a imprensa dos dois países. Portanto, a análise deve destacar o intercâmbio cruzado entre diplomacia e imprensa. Também deve abordar a questão do surgimento da diplomacia cultural nos dois países.

\section{Cultura diplomática e diplomacia cultural}

O duplo exercício da diplomacia e do jornalismo ajudou a conformar um intercâmbio transnacional, o qual, por sua vez, deu à diplomacia contornos de atividade de aproximaçáo cultural. Além de Olavo Bilac, dois outros personagens representaram essa tendência Martín García Mérou e Manuel de Oliveira Lima.

Mérou foi ministro plenipotenciário da Argentina no Rio de Janeiro entre 1894 e 1895. Autor de uma extensa obra literária e de crítica, foi também colaborador do La Nación. Após voltar a Buenos Aires publicou uma série de artigos em La Biblioteca sobre as letras brasileiras, reunidos em 1900 em um livro intitulado O Brasil intelectual, o qual tinha o objetivo de apresentar ao público argentino a produção letrada brasileira, com um nítido tom apologético. ${ }^{12}$ Ao mesmo tempo que o livro de Mérou era bem recebido no Brasil $1{ }^{13}$ seu autor ascendia na carreira diplomática, chegando a ser ministro em Washington e Berlim. Ainda que, evidentemente, não se possa atribuir a $O$ Brasil intelectual o sucesso de Mérou, é de se notar os vínculos entre o literato-diplomata e a imprensa brasileira, quando da aproximação entre Argentina e Brasil iniciada com a Proclamação da República. Uma das inúmeras expressóes dos trânsitos cruzados da diplomacia e do jornalismo através de alguns mediadores específicos pode ser vista também em uma fotografia publicada pela Caras y Caretas, capturando o momento em que Mérou dava as boas-vindas aos jornalistas brasileiros que acompanhavam Campos Sales. ${ }^{14}$

O historiador Manuel de Oliveira Lima viajou várias vezes à Argentina no final da década de 1910 convidado para fazer conferências em Buenos Aires e La Plata. Suas credenciais

\footnotetext{
${ }^{11}$ Colaboración de los periodistas brasileños/Nuestros huéspedes. Caras y Caretas, n. 108, 27 de outubro de 1900; De Olavo Bilac a PBT. P.B.T., n. 124, p. 88, 30 mar. 1907; Firmas brasileńas: dos sonetos de Olavo Bilac. Caras y Caretas, n. 1911, 18 maio 1935.

${ }^{12}$ MÉROU, Martín García. El Brasil intelectual: impresiones y notas literárias. Buenos Aires: Félix Lajouane, 1900.

${ }^{13}$ Ver, por exemplo, a crítica de VERÍSSIMO, José. Homens e cousas estrangeiras (1899-1908). Rio de Janeiro: Topbooks; Academia Brasileira de Letras, 2003, p. 491-501.

${ }^{14}$ Llegada de los periodistas y estudiantes brasileños. Caras y Caretas, n. 108, 27 out. 1900.
} 
de diplomata (aposentado) lhe abriram as portas de importantes instituiçóes argentinas, como a Faculdade de Direito da Universidade de Buenos Aires, e a importantes figuras políticas, como o presidente Hipólito Yrigoyen. Em 1920, Lima reuniu as conferências e vários capítulos de análise da realidade do país vizinho, publicando Na Argentina. Um dos objetivos era incrementar a "cordialidade internacional" entre os dois países, e o livro que Mérou havia escrito vinte anos antes era elogiado já na apresentação..$^{15}$ Lima era membro fundador da Academia Brasileira de Letras, que aceitara Mérou como membro correspondente em 1898. Também foi sócio correspondente do Instituto Histórico e Geográfico Brasileiro, instituiçáo que aceitaria na mesma categoria o ministro plenipotenciário argentino no Brasil Lucas Ayarragaray. Lima e Ayarragaray fariam parte do comitê executivo do Congresso Internacional de História da América de 1922, organizado pelo IHGB e realizado no Rio de Janeiro por ocasião das comemoraçóes do centenário da Independência.

Esta série de vínculos permite vislumbrar como os contatos estabelecidos em viagens e a produção de obras sobre as mesmas ajudava a estabelecer laços intelectuais. Contudo, os diplomatas profissionais não possuíam a agilidade necessária para cumprir a contento uma missão desse tipo, sobretudo em um momento em que o jornalismo se constituía em um novo campo de trabalho e de visibilidade para os escritores. Em uma época tida como de aceleração das comunicaçôes, a imprensa dava forma a um novo ritmo de troca de informaçóes internacionais, ${ }^{16}$ ao mesmo tempo que se alargava bastante o que se entendia por opiniáo pública a partir do crescimento do público leitor, sobretudo na Argentina. ${ }^{17}$ Rapidamente os jornalistas tiveram a autopercepção de ocuparem um local de prestígio na vida pública.

Os jornalistas também se valeram de uma simbiose com a literatura que vinha, ao menos no caso do Brasil, desde 1840, na medida em que muitos deles procuravam construir uma carreira literária. Essa interpenetração e seu papel de reforço da importância do jornalismo como ponte entre naçóes fica evidente na forma como o Correio Paulistano tratou a visita de Lorenzo Stanchini e Nicolás Olivari a São Paulo e Rio de Janeiro em 1925:

A presença desses espíritos entre nós tem a vantagem de acoroçoar os propósitos de conhecimento mútuo de que, teoricamente, os dois países estão animados, mas que o trabalho das etiquetas puramente diplomáticas não seria bastante para atingir. ${ }^{18}$

${ }^{15}$ LIMA, Manuel de Oliveira. Na Argentina (impressóes, 1918-1919). Rio de Janeiro e São Paulo: Weiszflog, 1920, p. 3.

${ }^{16}$ BARBOSA, Marialva. História cultural da imprensa (Brasil: 1900-2000). Rio de Janeiro: Mauad X, 2007, p. 21-26.

${ }_{17}$ PRIETO, Adolfo. El discurso criollista en la formación de la Argentina moderna. Buenos Aires: Siglo XXI, 2006; SARLO, Beatriz. El imperio de los sentimientos: narraciones de circulación periódica en la Argentina. Buenos Aires: Siglo XXI, 2011.

${ }^{18}$ Escritores argentinos. Correio Paulistano, 24 jan. 1925, p. 5. 
Todavia, a etiqueta diplomática tinha maior importância do que a linguagem algo parnasiana do redator paulista deixava entrever. Como se verá mais adiante, seus rituais e símbolos serão apropriados pelos jornalistas com tal intimidade que seria possível afirmar que o nascimento da diplomacia cultural na Argentina e no Brasil dependeu dessa apropriação. Raquel Paz dos Santos critica corretamente a historiografia da política externa brasileira quanto ao pressuposto de que apenas o Estado teria participado e conformado os processos de cooperação e de relaçôes internacionais. ${ }^{19}$ Como se nota aqui, o jornalismo adotou uma postura "diplomática" antes de haver um componente cultural nas políticas externas de ambos os países. Entretanto, a autora termina por não romper com a perspectiva criticada, ao marcar na década de 1930 o início de processos articulados de aproximação cultural, o que deriva da não inclusão da imprensa em sua análise. Santos estuda apenas as medidas implementadas pelos Estados argentino e brasileiro, via suas chancelarias. A ausência da imprensa também se nota na análise de Fernando Vale Castro, pois o autor se limita ao projeto cultural desenvolvido por uma publicação vinculada ao Itamaraty e à política desenvolvida pelo barão do Rio Branco, a Revista Americana.$^{20}$ Contudo, é de se notar que a revista por ele abordada circulou exatamente no auge da diplomacia cultural informal das "embaixadas" de jornalistas. Castro também ressalta com precisão que uma diplomacia cultural brasileira foi gestada na década de 1910 - e não na de 1920, como afirmam Dumont e Fléchet. ${ }^{21}$ Efetivamente, o trânsito de jornalistas aqui analisado demonstra que já na primeira década do século XX esta diplomacia cultural informal, levada a cabo de maneira semi-independente pela imprensa, estava em marcha acelerada, com seus contornos tendo se delineado por volta de 1890. Suplantando os limites dos dois estados nacionais, ela também teve uma inequívoca característica transnacional.

Alguns dos jornalistas tiveram evidente papel de mediadores culturais. Talvez quem mais personificou esta confluência entre o caráter teatral da diplomacia, a profissionalização do jornalismo e o circuito de viagens entre Argentina e Brasil tenha sido Ignacio Orzali, que esteve no Rio de Janeiro em cinco ocasióes, ora de passagem para a Europa, ora para estadas mais longas, viajando sozinho ou em grupo. Orzali também era figura assídua nas comissôes da imprensa portenha que recebiam seus contrapartes brasileiros. Sua presença se tornou táo costumeira que em sua última viagem um cronista carioca se referiu a ele como "velho camarada", 22 em uma informalidade que exprimia para o leitor a sedimentaçáo daquela cordialidade da qual falava, com uma linguagem mais protocolar, Oliveira Lima em seu livro.

\footnotetext{
${ }^{19}$ SANTOS, Raquel Paz dos. Relaçóes Brasil-Argentina: a cooperação cultural como instrumento de integração regional. Estudos Históricos, Rio de Janeiro, v. 22, n. 44, p. 355-375, jul./dez. 2009.

${ }^{20}$ CASTRO, Fernando Vale. Pensando um continente: a Revista Americana e a criaçáo de um projeto cultural para a América do Sul, op. cit.

${ }^{21}$ DUMONT, Juliette; FLÉCHET, Anaïs. Pelo que é nosso! A diplomacia cultural brasileira no século XX. Revista Brasileira de História, São Paulo, v. 34, n. 67, p. 203-221, jan./jun. 2014.

${ }^{22}$ HELIODORO, Bárbaro. Os figos. O Imparcial, 20 de outubro de 1920, p. 2. Bárbaro era o pseudônimo de Pedro da Costa Rego, que estivera em Buenos Aires pelo menos uma vez, em 1913, quando Orzali o recepcionou.
} 
É significativo que Orzali constasse de uma crônica escrita sob pseudônimo, na qual o argentino dialoga sobre os melhoramentos urbanos do Rio com o narrador brasileiro. É de se destacar a menção a Orzali como um personagem que não necessitava de apresentação para além de sua menção como participante da "original embaixada de argentinos que, sem protocolo, se constitui em caravana, empreendendo uma viagem de estudos pelo Brasil, por terra". ${ }^{23}$ A despeito do adjetivo que a precede, que parece indicar menos o inusitado do fato de jornalistas argentinos visitarem a cidade e mais o fato de ser por terra, ${ }^{24}$ a citaçáo deixa entrever o simbolismo diplomático e a função de aproximação cultural que o jornalismo adquirira nas relaçôes Argentina-Brasil. Também destaca determinados jornalistas, não apenas como condutores desta aproximação, mas como foco de curiosidade pública que a própria imprensa tratava de difundir. Já em 1890 a Gazeta de Notícias noticiava em primeira página a partida de Pardal Mallet a Buenos Aires, abaixo de uma ilustração do jornalista, e dez anos depois a revista Caras y Caretas estampava seis fotografias da comissão de jornalistas que acompanharam Campos Sales ao país vizinho. ${ }^{25} \mathrm{~A}$ publicação de fotos de visitantes iria se tornar um padrão, revelando, muitas vezes, os variados locais que marcavam as viagens: do convés aos salóes dos navios; das redaçôes de jornais às salas de banquete; das escadarias de palácios a parques públicos.

A originalidade de tais "embaixadas" era constantemente destacada. Todavia, se elas diferiam das verdadeiras pelo fato de náo envolverem agentes estatais, seus rituais eram muito similares. Neste aspecto, desapareceu a fronteira entre o jornalismo e a diplomacia, apagamento que partiu da imprensa, mas que contou com a ajuda de funcionários das chancelarias de ambos os países. Se havia diplomatas que interagiam com jornalistas, como García Mérou ou Oliveira Lima, havia também jornalistas que agiam como diplomatas. Não se trata tanto do fato de que jornalistas atuassem em funçôes oficiais, o que, a rigor, foi muito raro (mas nem por isso pouco emblemático). O que chama a atenção é o entendimento tácito, rapidamente construído, de que as visitas de jornalistas tinham um forte poder simbólico, capazes de estabelecer pontes entre as duas naçôes. Até mesmo entre homens de Estado, como se vê na disponibilidade de autoridades receberem os visitantes em seus gabinetes ou irem a suas comemoraçóes.

A imprensa percebeu a oportunidade e dela se aproveitou. As viagens contavam com uma organização que lembrava, em quase tudo, as comitivas dos grandes eventos oficiais. $\mathrm{Na}$ véspera do desembarque dos colegas brasileiros que viajavam a bordo do "Lutetia" em 1913, por exemplo, o jornal La Nación informava em detalhes a programação preparada para

\footnotetext{
${ }^{23}$ Idem.

${ }^{24}$ Também é possível especular que a originalidade da "embaixada" argentina se devia ao contraste com a recentemente encerrada estada do rei Alberto da Bélgica, motivo de grandes celebraçóes públicas e de grande empenho do cerimonial diplomático brasileiro. Ver: CAULFIELD, Sueann. Em defesa da honra: moralidade, modernidade e nação no Rio de Janeiro (1918-1940). Campinas: Editora da Unicamp; Cecult, 2000, p. 111-115. ${ }^{25}$ Pardal Mallet. Gazeta de Notícias, 8 ago. 1890, p. 1; Caras y Caretas, n. 108, 27 out. 1900.
} 
recebê-los, na qual se nota a uniáo da grande imprensa portenha e o apoio governamental: nos seis dias de estada os hóspedes seriam recebidos no porto pelo Círculo da Imprensa, visitariam as redaçôes, andariam no recém-inaugurado metrô, seriam recebidos na Casa Rosada e nos ministérios das relaçóes exteriores e da agricultura, iriam aos teatros (incluindo o Colón), visitariam o Congresso Nacional, participariam de banquetes (no Hipódromo de Palermo e no Hotel Savoy, entre outros lugares), excursionariam por La Plata (incluindo seu famoso museu arqueológico), e visitariam uma exposição agropecuária e o Museu Mitre. ${ }^{26}$ Desta forma, mantendo os rituais de recepçóes, passeios, almoços, idas ao teatro, visitas a redaçôes, associaçôes de classe e estadistas, a imprensa conseguia estreitar seus laços e ganhar proeminência frente aos ministérios das relaçôes exteriores.

A rigor, é possível identificar cedo a difusáo deste entendimento e deste desejo de situar a imprensa como veículo privilegiado das relaçóes bilaterais. Ori Preuss destacou o descompasso entre a resposta fria do governo brasileiro à comemoração da Abolição da escravidão ocorrida em 1888 nas ruas portenhas e aos elogios, ediçóes especiais e discursos laudatórios da imprensa daquela capital e o entusiasmo de representantes da sociedade civil, como grupos de militares, membros da associaçôes abolicionistas e jornalistas. Além de imprimir artigos retribuindo os elogios vindos da imprensa argentina, os jornais do Rio de Janeiro organizaram uma festa para o 9 de julho, no qual lançaram ediçóes especiais que, segundo esses mesmos jornais, teriam sido enviadas a Buenos Aires. ${ }^{27}$ Enquanto isso, seus representantes no país vizinho eram tratados como convidados de honra e apresentados ao público portenho como em missão de aproximação entre as duas naçôes.

Mais de uma década depois, quando da visita de Campos Sales a Julio Roca, a revista Don Quijote publicou uma "Alegoria de atualidade" de duas páginas (Figuras 1 e 2), na qual eram retratados os dois presidentes em uma carruagem, com escolta de cavalaria, quatro Mariannes representando as duas repúblicas confraternizando e, no entorno, retratos de alguns jornalistas brasileiros que acompanharam Sales: Olavo Bilac, Antônio Carlos Simóes da Silva, Carlos Seidl, Francisco Guimaráes, Alfredo Gomes de Almeida e Álvares de Azevedo. É interessante notar que nessa ilustração a imprensa é parte constituinte da confraternização binacional. Sua posição no entorno do desenho, fora da ação que envolve a carruagem, os cavaleiros e as Mariannes, sugere um destaque especial. Enquanto os dois presidentes necessitam dos símbolos nacionais e dos aparatos do poder, a imprensa necessita apenas da imagem de seus membros. Há como que um vínculo com o rico álbum contendo a programação da recepção à comitiva presidencial mandado elaborar pelo governo argentino, no qual se incluíra a imprensa, através, entre outros elementos, das biografias dos jornalistas da comitiva, encimadas por seus retratos. ${ }^{28}$

\footnotetext{
${ }^{26}$ Los periodistas brasileños: programa de agasajos. La Nación, 19 nov. 1913, p. 16.

${ }^{27}$ PREUSS, Ori. Bridging the island: Brazilians'views of Spanish America and themselves, 1865-1912, op. cit. ${ }^{28}$ PEÑA, Cipriano de La. Crónica ilustrada y comentada de las fiestas de confraternidad brasilero-argentinas. Buenos Aires: Compañía Sud-americana de Billetes de Banco, 1901, p. 56-63.
} 


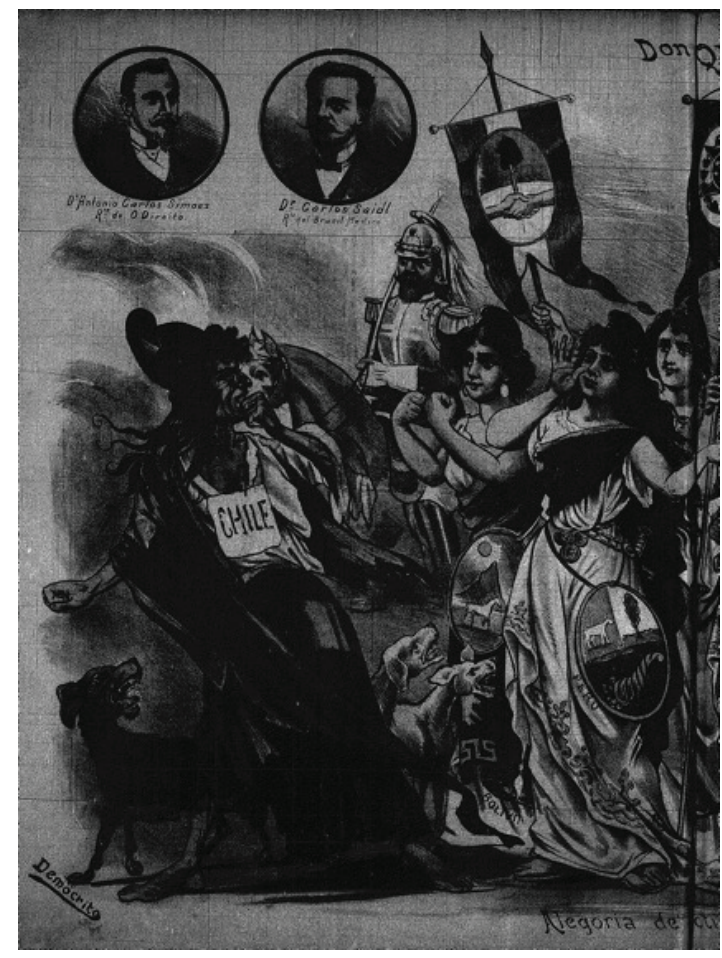

Figura 1: Don Quijote, n. 11, 28 out. 1900. Ilustração (detalhe) de Eduardo Sojo.

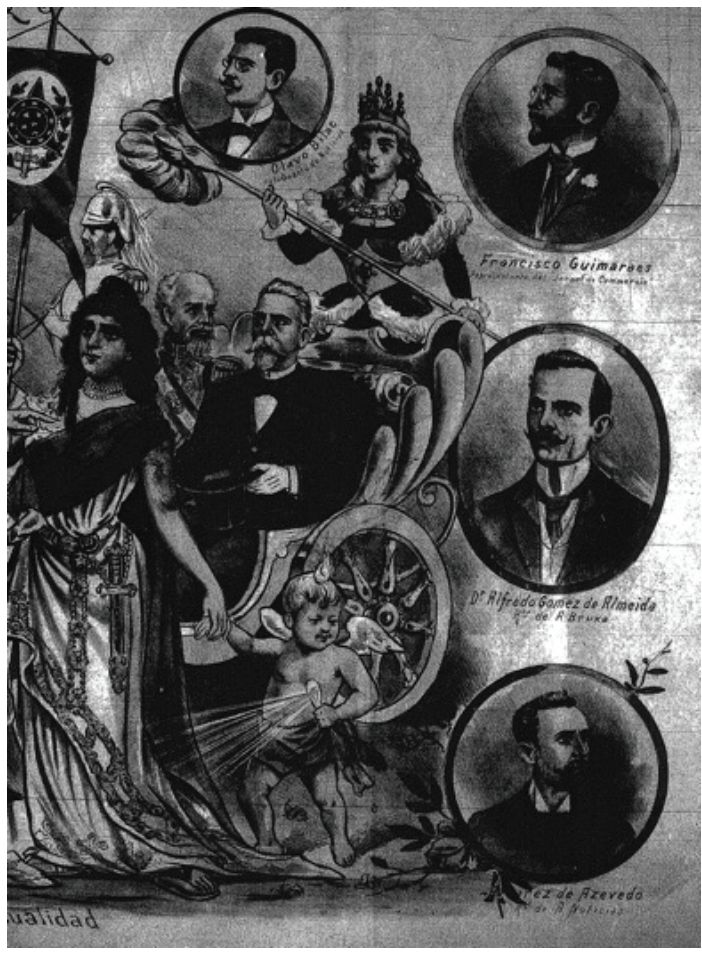

Figura 2: Don Quijote, n. 11, 28 out. 1900. Ilustração (detalhe) de Eduardo Sojo.

Também a história de atritos entre os dois países passava a ser vista sob nova perspectiva. Em 9 de julho de 1888, no contexto da retribuição aos festejos portenhos pela Abolição da escravidão, a Gazeta de Notícias publicou uma edição especial em comemoração à independência argentina, no que pode ser descrito como um exercício diplomático do jornal. ${ }^{29}$ Além de grandes manchetes (algo raro naquele período) saudando a data, cada um de seus cronistas escreveu um texto dedicado ao tema. Entre eles estava Machado de Assis, o qual afirmou que

em vez de soldados que os vão auxiliar a derrocar uma tirania odiosa, mandamos-lhe uma simples comissão de jornalistas, uma embaixada da opiniáo à opinião; táo confiados somos de que não há já entre nós melhor campo de combate. ${ }^{30}$

$\mathrm{O}$ cronista se referia à superação da fase em que a amizade argentino-brasileira se expressava na aliança militar, como na firmada em 1852 contra o governador de Buenos Aires Juan Manuel de Rosas e em 1865 contra o Paraguai. ${ }^{31}$ Mas também fazia referência à diplomacia

\footnotetext{
${ }^{29}$ Agradeço ao parecerista anônimo que chamou a atenção para este ponto.

${ }^{30}$ ASSIS, Machado de. O futuro dos argentinos. Gazeta de Notícias, 9 jul. 1888, p. 1.

${ }^{31}$ Para uma apreciação das crônicas sobre a Argentina na imprensa brasileira, consultar: RODRIGUES, João Paulo C. S. Da revolução à regeneração: crônicas de Machado de Assis e de Olavo Bilac sobre a Argentina, Antiteses, Londrina, v. 6, n. 11, p. 127-148, jan./jun. 2013.
} 
como esfera de conflitos. Efetivamente, no início da década de 1870 Argentina e Brasil discordaram quanto à interpretação dos acordos da Tríplice Aliança que derrotou o Paraguai. Assim, o significativo, para Machado de Assis, era a mudança de características da relação bilateral, não mais apenas ditada pela guerra, mas também pelo sentimento da "amizade" que o linguajar diplomático tendia a tornar meramente metafórico, "amizade" esta que somente podia vicejar quando corporificada em uma esfera social que, embora vinculada ao Estado, dele não dependia: a opinião pública, ou, em outras palavras no conjunto de periódicos que lhe dava forma. Esta esfera convivia com os atritos diplomáticos, na medida em que se colocava ao lado dela. Portanto, aquilo que na crônica parece ser frágil — a "simples comissão de jornalistas" — é, na realidade, um ato fundador de alta relevância — "uma embaixada da opinião à opinião". ${ }^{32}$

A linguagem do noticiário (telegramas, crônicas, entrevistas e transcrição de discursos) foi um elemento importante a delinear as relaçôes exteriores levadas a cabo pela imprensa. Os jornalistas se apropriaram da retórica diplomática de forma indisfarçável. Como mencionava Machado de Assis, a noção central era a da "amizade". Sobre ela não é necessário alongar-se, tal é a transparência com que deixava entrever o sentido de uma diplomacia informal levada a cabo por jornalistas que, fora do circuito das viagens, pouco contato mantinham..$^{33}$ Contudo, um tópico subordinado a esta noção requer uma mençáo mais detida: o da hospedagem. O constante tratamento dos jornalistas como "hóspedes"34 não somente revelava para os leitores uma posição especial e a deferência daí derivada, como justificava os gastos e o tempo dedicado pela imprensa e pelos governos na preparação dos passeios oferecidos aos visitantes. Ao mesmo tempo, reforçava simbolicamente a imprensa como veículo e agente da aproximação entre os dois povos, na medida em que os "hóspedes" seriam, na volta à casa, os transmissores de uma mensagem de aproximação internacional. Era esta convicção que parecia mover a declaração de Ignacio Orzali, em uma de suas passagens pelo Rio de Janeiro a serviço do La Nación, para quem a razáo de sua estada era "para que eu veja e tente

\footnotetext{
${ }^{32}$ Cabe mencionar outro uso do termo, desta vez por um diário portenho, que assim define a recepção pelo ministro das relaçôes exteriores brasileiro Lauro Müller: "Os jornalistas argentinos foram acolhidos por ele como verdadeiros embaixadores, ainda quando não luzissem casacas bordadas nem fossem portadores de credenciais, nem extensos os protocolos entre a meticulosa tarefa dos conselhos de gabinetes." Em: Los periodistas argentinos en el Brasil — una visita al canciller Lauro Müller. El Diario, 22 dez. 1913, p. 4 (traduçáo do autor). O termo "embaixada" em referência a jornalistas apareceria ainda em: Vida social: Manuel Láinez/viajantes. $O$ Pais, 11 maio 1922, p. 4; Noticiário elegante. Revista da Semana, n. 21, 20 maio 1922; Embaixatriz das letras brasileiras e pelo próprio Brasil. O Imparcial, 3 nov. 1922, p. 9.

33 Outros exemplos, dentre tantos, em que a imprensa valorizou a "amizade" (e a "cordialidade") nestes encontros pode ser vista em: À República Argentina. Diário de Notícias, 9 jul. 1888, p. 1; Los periodistas brasileños. La Nación, 24 nov. 1913, p. 11.

${ }^{34}$ Este termo é utilizado no título ou no corpo de inúmeras matérias, destacando-se: Llegada de los periodistas y estudiantes brasileńos. Caras y Caretas, n. 108, 27 out. 1900; O nosso hóspede o general Roca. Gazeta de Notícias, 14 mar. 1907, p. 1; Huéspedes brasileños — recepción en el Círculo de la Prensa. La Razón, 20 nov. 1913, p. 7; El Sr. Pablo Barreto. El Diario, 18 maio 1915, p. 4; Viajantes. O País, 9 maio 1922, p. 4; Artes e artistas: hóspedes ilustres. O País, 29 abr. 1926, p. 4; Hóspedes e viajantes. O Jornal, 25 dez. 1930, p. 13.
} 
os meios para levar a efeito a maior e mais rápida aproximação intelectual e política entre os dois povos, por meio das duas imprensas". ${ }^{35}$

Neste jogo de referências, a ideia de simplicidade veiculada pela crônica de Machado de Assis mencionada acima ficava deslocada. Efetivamente, raras foram as viagens - sobretudo antes de 1920 - que abdicaram do fausto e elegância associados ao protocolo diplomático em suas atividades mundanas. Um exame mais detido dos textos e imagens do noticiário, de crônicas e de alguns documentos avulsos permite delinear melhor a difusão de uma sociabilidade burguesa associada aos modos da diplomacia.

\section{Roteiros, rituais e sociabilidades}

Em boa medida, as "embaixadas" da imprensa seguiam o protocolo diplomático, que, por sua vez, estava marcado por uma integração às sociabilidades burguesas elaboradas no século XIX, com suas matrizes em Paris e em Londres, nas quais se destacam os parques, os clubes e associaçôes, os restaurantes e os hotéis. Não se deve esquecer, todavia, que ela incorporou elementos da civilidade de tipo aristocrático do século anterior, como a alta cozinha e os banquetes ritualizados. Esse vínculo não era surpreendente, uma vez que as sociabilidades de tipo burguês (emanadas da sociedade civil, associativa, igualitarista) incorporaram alguns elementos da civilidade de tipo nobre (emanada da vida cortesã, hierarquizada), como a etiqueta e a arte da conversação.

Dificilmente poderia ser diferente em uma América do Sul cujas elites estavam atentas aos hábitos europeus. ${ }^{36}$ Ao mesmo tempo, as duas décadas finais do século XIX presenciaram a montagem de regimes liberal-oligárquicos que dependiam de uma série de espaços de vínculo social de caráter exclusivista que serviam para arregimentar seus beneficiários e alocá-los em posiçóes dentro do sistema. Entende-se assim o rebaixamento do café, originalmente um espaço central de sociabilidade burguesa, de caráter mais democrático, mas que ao longo do século passou a ser visto como local de encontro das camadas médias e populares ou da boemia. O café também havia sido, junto às livrarias e redaçôes de jornais e revistas, um dos principais núcleos da sociabilidade intelectual. ${ }^{37}$

\footnotetext{
${ }^{35}$ A Argentina e o Brasil — "Interview” da Gazeta com o secretário do Nación. Gazeta de Notícias, 18 ago. 1910, p. 2.

${ }^{36}$ É provável que o surgimento de um circuito de viagens de artistas, cientistas e intelectuais europeus pela América do Sul tenha reforçado elementos desta sociabilidade, assim como os roteiros de recepção de visitantes estrangeiros. A este respeito, ver: BRUNO, Paula (Org.). Visitas culturales en la Argentina, 1898-1936, op. cit.

${ }^{37}$ RODRIGUES, João Paulo Coelho de Souza. A geração boêmia: vida literária em romances, memórias e biografias. In: CHALHOUB, Sidney; PEREIRA, Leonardo Affonso de Miranda (Org.). A história contada: capítulos de história social da literatura no Brasil. Rio de Janeiro: Nova Fronteira, 1998, p. 233-264; QUIRÓZ, Pilar González Bernaldo de. Civilidad y politica en los orígenes de la nación argentina: las sociabi-
} 
Havia, evidentemente, uma série de intercâmbios entre cafés e instituiçóes. Alguns membros de círculos, institutos, ateneus e academias letradas também eram boêmios. Todavia, no final do século cada espaço estava demarcado pela linha da respeitabilidade e da etiqueta, demandando comportamentos distintos. Paralelamente, avolumaram-se as associaçôes recreativas, que possuíam uma forte clivagem classista, étnica e nacional, como, por exemplo, as sociedades esportivas de imigrantes. Para o final do século, algumas associaçóes recreativas seriam as instituições centrais do que passou a ser conhecido como "alta sociedade" (em oposiçáo à simples "sociedade", termo que, em boa parte do século XIX, significara justamente a pequena parcela "decente" e "educada" da população). ${ }^{38} \mathrm{O}$ surgimento, a partir de Caras y Caretas (1898) e de O Malho (1902), de semanários ricamente ilustrados a cores, de literatura ligeira, com amplas seçôes de propagandas de caros produtos importados de luxo e que cobriam amplamente as festas e encontros da elite (com destaque para as recepçôes diplomáticas), atesta a força desta mudança. ${ }^{39}$

Devido aos relatos fortemente formalizados e situados na esfera da exaltação constante da cordialidade, pode-se apenas especular sobre os encontros entre jornalistas argentinos e brasileiros. Mas náo seria ilusório imaginar que seu comportamento não seguia sempre o protocolo em toda sua extensáo, com prováveis momentos de informalidade interrompendo as festividades marcadas pela etiqueta.

Há indícios de que a sociabilidade iniciava-se durante a travessia marítima. A modernização da navegação, ao permitir um fluxo mais intenso e rápido de rotas entre Europa e América do Sul, facilitou o trajeto entre as capitais do Brasil e da Argentina, que levava em média uma semana no início da década de 1880 , e passou a levar apenas três dias no final da década seguinte, mantendo-se estável até a Segunda Guerra Mundial. De um lado, essa facilidade incentivou o envio de correspondentes internacionais. De outro lado, o incremento da calagem dos navios permitiu o aumento do número de passageiros. Todas essas transformaçóes podem ter estimulado um novo tipo de contato entre argentinos e brasileiros. Um indício é fornecido pela literatura de viagem argentina e brasileira da época, na qual o tema das atividades de bordo e os conhecimentos travados entre viajantes ganham destaque..$^{40}$ Também na imprensa a sociabili-

lidades en Buenos Aires, 1829-1862. Buenos Aires: Fondo de Cultura Económica, 2008; GAYOL, Sandra. Sociabilidad en Buenos Aires: hombes, honor y cafés, 1862-1910. Buenos Aires: Ediciones del Siglo, s.d.; ANSOLABEHERE, Pablo. La vida bohemia en Buenos Aires (1880-1920): lugares, itineraries y personages. In: BRUNO, Paula (Org.). Sociabilidades e vida intelectual: Buenos Aires, 1860-1930. Bernal: Universidad Nacional de Quilmes, 2014, p. 155-185.

${ }^{38}$ NEEDELL, Jeffrey D. Belle Époque tropical: sociedade e cultura de elite no Rio de Janeiro na virada do século. São Paulo: Companhia das Letras, 1993.

${ }^{39}$ ROGERS, Geraldine. Caras y Caretas: cultura, politica y espetáculo en los inicios del siglo XX argentino. La Plata: Universidad Nacional de La Plata, 2008; OLIVEIRA, Cláudia de; VELLOSO, Monica Pimenta; LINS, Vera. O moderno em revista: representaçôes do Rio de Janeiro de 1890 a 1930. Rio de Janeiro, Garamond, 2010. ${ }^{40}$ Ver: PRADO, Eduardo. Viagens: América, Oceania e Ásia. São Paulo: Escola Tipográfica Salesiana, 1902, p. 9-11; CANÉ, Miguel. En viaje [1883]. Caracas: Fundación Ayacucho, 2005, p. 33; WILDE, Eduardo. Viajes y observaciones: cartas a La Prensa. Buenos Aires: Martín Biedma, 1892, p. 5-29, v. I; GROUSSAC, 
dade de bordo foi objeto de interesse, como se vê na Figura 3, que retrata uma confraternização entre oficiais franceses e jornalistas brasileiros e argentinos.

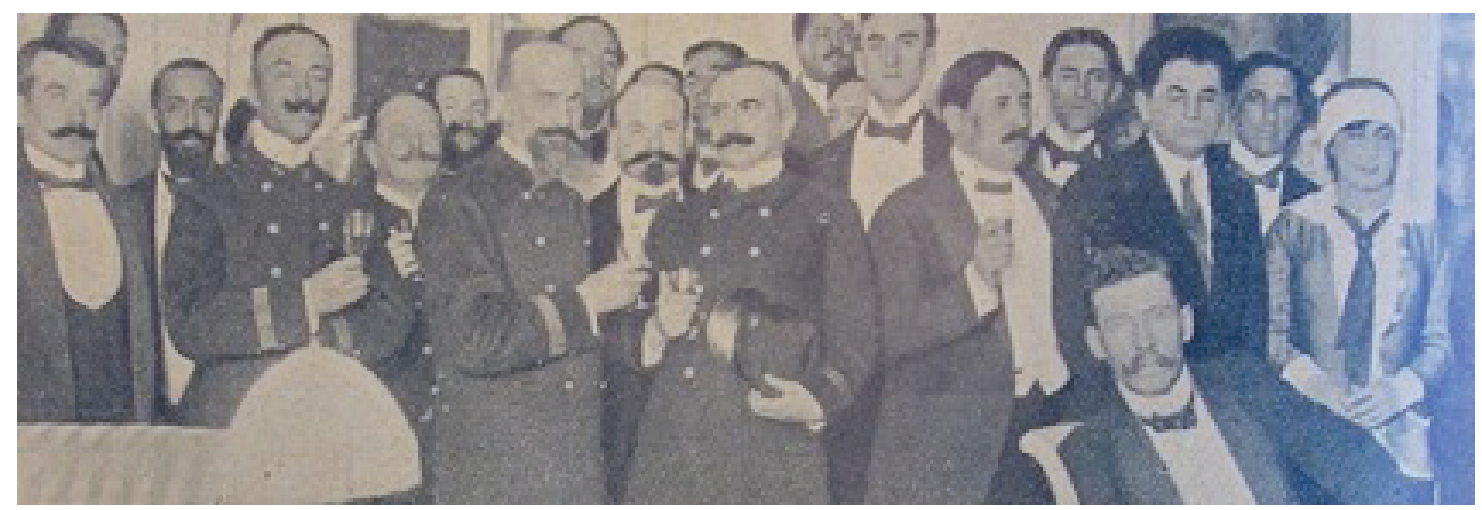

Figura 3: P.B.T., n. 474, 27 dez. 1913.

A etiqueta também estava no centro do noticiário que a imprensa dos dois países dedicava aos encontros em solo firme. A se crer nos telegramas, crônicas e fotografias, os roteiros se mantiveram estáveis entre as décadas de 1890 e 1920, com ênfase nos banquetes, nos encontros com autoridades, nos passeios pelos bairros elegantes e nas visitas a algumas instituiçóes públicas. Este roteiro representava a formação de uma rede cultural e de um campo jornalístico como representação nacional não só por sua regularidade, mas também pelos discursos que geravam e pela cobertura da imprensa que recebiam.

Os registros da imprensa mostram que os argentinos visitavam a avenida Central/Rio Branco e imediaçóes, o Catete e o Corcovado, com ocasionais idas a Petrópolis e São Paulo. Enquanto isso, os brasileiros circulavam pela rua Florida e pela avenida de Mayo, e pelos bairros elegantes de Palermo, Belgrano e Recoleta, com ocasionais excursōes a La Plata. Nesses espaços estavam os respectivos Congressos nacionais, os palácios presidenciais, e as prefeituras. No caso de Buenos Aires, estavam também o Club del Progreso ${ }^{41}$ e o teatro Colón. Um passeio comum oferecido aos visitantes era ir de barco até o município de Tigre, no estuário do Rio da Prata, onde a alta burguesia mantinha clubes de iatismo e remo. Nas duas capitais prevalecia entre aquele estrato social uma série de lazeres de origem inglesa, refletidos, principalmente, nos respectivos Jockeys Clubs. Neles se realizaram de simples visitas a faustosos lunchs, passando pelo serviço de chá.

Paul. Del Plata al Niágara. Buenos Aires: La Biblioteca, 1897, p. 50-58; DIAS, Artur. Do Rio a Buenos Aires. Rio de Janeiro: Imprensa Nacional, 1901, p. 3-86.

${ }^{41} \mathrm{O}$ "Club del Progreso" foi o primeiro do gênero da Argentina. Seguia o modelo inglês e em 1900 se mudou para uma imponente sede na Avenida de Maio, reafirmando sua centralidade na sociabilidade das elites em Buenos Aires. A este respeito, consultar: QUIRÓZ, Pilar González Bernaldo de. Civilidad y política en los origenes de la nación argentina: las sociabilidades en Buenos Aires, 1829-1862, op. cit., p. 328-336. 
Nas visitas coletivas e de diretores, secretários de redação e proprietários de diários as formas mais constantes de expressão da aproximação — na ótica dos envolvidos - entre as duas naçôes foram os banquetes e as visitas às redaçôes, as quais, no caso dos diários de maior circulação, se encontravam na avenida Central e na avenida de Mayo. Em ambos os casos, a etiqueta mandava que se levantassem brindes e se pronunciassem discursos. A imprensa registrou alguns dos locais de lunchs (os jantares parecem ter sido raros, o que abre espaço para se especular que as noites eram reservadas para atrativos mais boêmios): a Câmara Mercantil, o Hipódromo de Palermo, o Circulo de la Prensa, a Rotisserie Charpentier, e os restaurantes dos hotéis Paris e Savoy, no caso de Buenos Aires; os palacetes de José Carlos Rodrigues (diretor do Jornal do Comércio) e de Fernando Mendes de Almeida (diretor do Jornal do Brasil), o Jockey Club, e os restaurantes do Teatro Municipal, do Palace Hotel e da estaçáo do Sumaré, no caso do Rio de Janeiro.

Talvez a melhor expressão dessa etiqueta de origem franco-inglesa, que era absorvida das sociabilidades burguesas e do protocolo diplomático, fosse o hábito de se elaborarem menus especiais. Lúcia Garcia reuniu e analisou os que foram colecionados por Olavo Bilac. Além dos aspectos estéticos e gráficos luxuosos (qualidade do papel, tipos de letras, ilustraçôes), os cardápios possuem três elementos recorrentes: o registro do evento ao qual a refeição se referia, a listagem em francês dos pratos e bebidas oferecidos e, no caso dos encontros de jornalistas, a assinatura dos presentes. ${ }^{42}$ Os cardápios da coleção são muito similares aos dos banquetes diplomáticos. Se a eles se juntarem as fotografias e os relatos da imprensa (que vez ou outra também listavam os pratos degustados), nos quais se resumem ou transcrevem inumeráveis brindes e discursos, aumentam as semelhanças. A coleção de Bilac também permite perceber seu papel de mediador entre os jornalistas dos dois países e a construção da imprensa como um agente diplomático informal, seja através de sua presença nos banquetes oficiais, seja porque o poeta também era um organizador de reunióes gastronômicas. Em 13 de março de 1907, por exemplo, Bilac ofereceu a Julio Piquet, enviado do La Nación para a cobertura da escala de Julio Roca em direção à Europa, um almoço no restaurante da estação Sumaré do trem para o Corcovado, no que a revista $O$ Malho descreveu como um "alto requinte de gentileza fidalga”. ${ }^{43}$ Curiosamente, o cardápio foi impresso em português, ${ }^{44}$ talvez porque se esperasse que o encontro dispensasse algumas formalidades. A Gazeta de Notícias descreveu a festa como "uma homenagem da imprensa e das literaturas brasileiras à imprensa e à literatura argentinas", ao mesmo tempo que afirmou que os jornalistas "confraternizaram, não com essa gentileza convencional que há em todas as festas a que comparecem cavalheiros distintos, mas com ver-

\footnotetext{
${ }^{42}$ GARCIA, Lúcia. Para uma história da Belle Époque: a coleção de cardápios de Olavo Bilac. Rio de Janeiro: Academia Brasileira de Letras; São Paulo: Imprensa Oficial do Estado de São Paulo, 2011.

${ }^{43}$ O Malho, n. 236, 23 mar. 1907.

${ }^{44}$ GARCIA, Lucia. Para uma história da Belle Époque: a coleção de cardápios de Olavo Bilac, op. cit., p. 104-105.
} 
dadeira simpatia, diremos mesmo amizade íntima". ${ }^{45}$ Qualquer que tenha sido o grau de informalidade que o almoço adquiriu, sua preparação (cardápio requintado, restaurante exclusivo) e a cobertura da imprensa (notícias, relatos e fotografias dos encontros) se adequam aos padróes de recepção de jornalistas como "embaixada", assim como a abrangência e importância dos presentes confirma o papel mediador de Olavo Bilac. ${ }^{46}$

Outra atividade recorrente e, a rigor, mais duradoura, uma vez que os banquetes rarearão na década de 1920, eram as visitas às redaçôes dos periódicos e à sede do Círculo de la Prensa e da Associaçáo Brasileira de Imprensa. Os diários registravam as visitas e as revistas publicavam as fotografias de visitantes e anfitriōes. O ritual era orientado no sentido de representar a chegada de "embaixadas", com conversas amenas, brindes e pausas para fotos. Neste sentido, a presença de jornalistas estrangeiros efetivamente exercitando o jornalismo parece ter sido rara e tardia, como foi o caso da cessão de uma mesa na redação de $O$ Jornal para que Roberto Arlt escrevesse suas crônicas sobre o Rio de Janeiro para El Mundo. ${ }^{47}$

O aparente privilégio concedido a Arlt em 1930, quando os rituais elegantes haviam rareado, se originava também no fato de o escritor viajar sozinho. No caso das comitivas náo havia muito tempo e espaço para escrever e os visitantes eram constantemente entretidos com passeios e reuniōes, oficiais e mundanas, o que dava vazão a outro elemento da etiqueta ao mesmo tempo literária, política e diplomática: os discursos. Olavo Bilac, em crônica publicada pela Gazeta de Notícias em 28 de outubro de 1900, assim os ironizou:

Não conto, não tenho palavras para contar tudo o que nos fez desvairar nas primeiras vinte e quatro horas. Não sabíamos de nós; agora mesmo apenas sei que estou falando pelo telefone, mas dizer se estou na terra ou no céu, náo sei. Vivemos à mesa, na rua, no teatro, a passear, a dançar, a ouvir e fazer discursos, e vê-los imprimir. O meu segundo discurso saiu impresso da boca. ${ }^{48}$

As exigências das festividades coletivas faziam com que a possibilidade de contatos mais extensos entre visitantes e membros do campo intelectual local se desenvolvesse nas visitas individuais ou de pequenos grupos, o que resultava não só em uma coleta de informaçôes

\footnotetext{
${ }^{45}$ O nosso hóspede o general Roca. Gazeta de Notícias, 14 mar.1907, p. 1.

${ }^{46}$ Estiveram no Sumaré, além do homenageado e do anfitrião: Miguel Abunes (Caras y Caretas); Enrique García Velloso (El País e Diário Español); J. A. Manuel Ruiz (La Razón); César Maureso e Modesto San Juan (P.B.T.); Belisário Roldán (Tribuna); Mujica Linares (La Prensa); Alberto Botelho (O Malho); Figueiredo Pimentel (Gazeta de Notícias); Antenor Sabrosa (Revista da Semana); Paulo Barreto; Manoel Bonfim; José do Nascimento (Diário de Notícias); Gabriel Pinheiro (Século); Ernesto Sena; Filinto de Almeida; Oscar Lopes; Paulino Botelho (Kosmos); Arthur Azevedo: Medeiros e Albuquerque. Há fotografias do encontro em: Renascença, n. 37, mar. 1907 e O Malho, n. 236, 23 mar. 1907.

${ }^{47}$ ARLT, Roberto. Na caverna de um compatriota (05/04/1930) e Redação de O Jornal (13/05/1930). In: ARLT, Roberto. Águas-fortes portenhas seguidas de água-fortes cariocas. Rio de Janeiro: Iluminuras, 2013, p. 264-266 e p. 349-351.

${ }^{48}$ DIMAS, Antônio (Org.). Bilac, o jornalista: crônicas, volume 1. São Paulo: Edusp; Editora da Unicamp; Imprensa Oficial, 2006, p. 382.
} 
que os visitantes posteriormente poderiam compartilhar com seus colegas e amigos, nos cafés, livrarias, academias e instituiçôes congêneres, mas também na difusão dos livros escritos por hóspedes e anfitrióes. As notícias de chegadas de jornalistas quase sempre listavam sua produção, por exemplo. No sentido inverso, ou seja, na volta para casa, os viajantes podiam levar na bagagem exemplares da literatura local, como se verá a seguir.

\section{Bibliotecas e mediação intelectual}

O primeiro caso parece ter sido García Mérou, que se apresentava como um pioneiro na aproximação cultural e intelectual entre as duas naçôes. Ao chegar ao Rio como ministro argentino, foi a pelo menos uma redaçáo, na qual trocou exemplares de seus livros pelos de literatos e jornalistas brasileiros. ${ }^{49}$ Ao escrever os artigos sobre a intelectualidade brasileira para La Biblioteca, talvez Mérou estivesse retribuindo a boa acolhida que recebeu, pois o leitor argentino era apresentado a uma extensa lista de autores brasileiros, ${ }^{50} \mathrm{da}$ literatura, $\mathrm{da}$ crítica, do direito e da política, como Sílvio Romero, José Veríssimo, Gonçalves de Magalhães, José de Alencar, Tobias Barreto, Joaquim Francisco de Assis Brasil, Joaquim Nabuco e Rui Barbosa - entre outros. A imprensa brasileira também mereceu algumas considerações suas. Em todo o caso, a reuniáo de seus artigos saiu do prelo em setembro de 1900, um mês antes da chegada de Campos Sales, e pelo menos um exemplar foi enviado através da comitiva da imprensa brasileira ao senador Rui Barbosa, que também era proprietário e principal redator de $A$ Imprensa. ${ }^{51}$

$\mathrm{Na}$ sua réplica ao diplomata argentino, Oliveira Lima apresentou ao leitor brasileiro um amplo panorama da intelectualidade argentina, tratando de Bartolomé Mitre, Domingo F. Sarmiento, Juan B. Alberdi, Ricardo Rojas, Estanislao Zeballos, José Ingenieros, Lucas Ayarragaray, Leopoldo Lugones, Juan Agustín Garcia, Hugo Wast (pseudônimo de Gustavo Adolfo Martinez Zuviria), Carlos Octavio Bunge, Clemente L. Fregueiro, Ricardo Levene, Ernesto Quesada, Ramón J. Cárcano, Antonio Dellepiane e Diego Luiz Molinari.52

As viagens eram também oportunidades para se adquirir exemplares da produção local. Tomás Lopes e Mário Brant informaram a compra de obras argentinas - embora sem especificar autores ou títulos..$^{53}$ Ignacio Orzali revelou em entrevista concedida durante sua

\footnotetext{
${ }^{49}$ A Semana, n. 48, 30 jun. 1894, p. 383.

${ }^{50}$ MÉROU, García. El Brasil intelectual: impresiones y notas literárias, op. cit.

${ }^{51}$ Ver carta de Mérou a Barbosa, de novembro de 1900 (Arquivo Rui Barbosa/Seção Correspondência/Fundação Casa de Rui Barbosa). Disponível em: < http://docvirt.com/docreader.net/DocReader.aspx?bib=ArquivoRuiBarbosa\&PagFis=15077\&Pesq=>. Acesso em: 23 set. 2016.

${ }^{52}$ LIMA, Oliveira. Na Argentina (impressóes, 1918-1919), op. cit., p. 30-33 e p. 134-186.

${ }^{53}$ LOPES, Tomás. Buenos Aires. Kosmos, n. 5, maio 1908; BRANT, Mario. Viagem a Buenos Aires. Rio de Janeiro: Fundo Editorial AAFBB, 1917, p. 32.
} 
estada em 1910 a aquisição de "uma biblioteca brasileira", ${ }^{54}$ composta de guias turísticos, dicionários, almanaques, livros de história, obras sobre política e crítica literária, entre outros gêneros. Orzali lamentava que poucos livros brasileiros pudessem ser encontrados em Buenos Aires, mas é interessante notar que ele carregara consigo, em sua visita de 1906, exemplares da tradução do romance Esaú e Jacó para seu autor, Machado de Assis. Essa tradução fora feita para a coleção Biblioteca de La Nación, e o editor do jornal, Luis Mitre, enviara pelo portador uma carta ao escritor brasileiro. ${ }^{55}$ Luis era neto de Bartolomé Mitre, fundador do diário portenho, que havia sido elogiado em 1888 por Assis na crônica publicada no número especial da Gazeta de Notícias sobre a independência argentina, mencionada acima. Ao desembarcar no Rio alguns dias depois da visita de Olivari em 1910, foi recebido por uma comitiva da Associação Brasileira de Imprensa. A Gazeta de Notícias relatou em primeira página sua chegada como o desembarque de uma alta autoridade. Também é interessante notar que o título da reportagem não faz referência à nacionalidade do editor, pressupondo uma familiaridade do leitor com Mitre. ${ }^{56}$

Por fim, cabe mencionar a visita de Oscar de Carvalho Azevedo, da Agência Americana do Rio de Janeiro, a qual lhe rendeu mais de cem livros ofertados pelo ministro das Relaçóes Exteriores José Luis Murature e pelo La Nación, com o objetivo os distribuir entre bibliotecas públicas cariocas, o que foi descrito pelo diário $A$ Notícia como ato de consolidação das "relaçôes literárias" entre os dois países. ${ }^{57}$

\section{Refluxo das "embaixadas"}

$\mathrm{Na}$ década de 1920 praticamente não ocorreram mais viagens coletivas, retomadas na década de 1930 no contexto de nova troca de visitas presidenciais e da inauguração de transatlânticos e linhas aéreas. As referências a elaborados programas de recepção aos jornalistas desapareceram. No caso das viagens presidenciais de 1933 e 1935, quase nenhuma menção foi feita aos que acompanhavam as comitivas oficiais, e nota-se um contraste entre a profusão de fotos de militares e diplomatas, e a ausência de retratos de jornalistas.

\footnotetext{
${ }^{54}$ A Argentina e o Brasil — interview da "Gazeta” com o secretário de "La Nación”. Gazeta de Notícias, 18 ago. 1910, p. 2.

${ }_{55}$ ROCCA, Pablo. Machado de Assis, escritor do Rio da Prata: duas hipóteses contraditórias. Cadernos de Letras da UFF, Niterói, n. 38, p. 45-46, jan./jul. 2009.

${ }^{56}$ Um jornalista eminente - a chegada do Dr. Luis Mitre — a sua recepção. Gazeta de Notícias, 25 ago. 1910 , p. 1.

${ }^{57} \mathrm{O}$ diretor da Agência Americana. A Notícia, 24 jun. 1914, p. 1. No ano seguinte Paulo Barreto distribuiu seus livros nas redaçóes de jornais portenhos. Ver: En honor de Joao do Rio. El Diario, 18 abr. 1915, p. 1.
} 
O sentido de "embaixada" também se alterou. Como salienta Martin Wight, ${ }^{58}$ o termo passou a indicar no século XV uma representação diplomática permanente. Até a Segunda Guerra Mundial admitia-se, salvo poucas exceçóes (como os Estados Unidos), que somente as potências europeias trocassem entre si embaixadores fixos. Os demais países — entre si e na Europa - mantinham apenas ministros plenipotenciários, sendo o local onde se situava sua representação diplomática conhecido como "legação". Na primeira metade do século $\mathrm{XX}$, por exemplo, foi tido como uma grande conquista a elevação ao patamar de embaixada das representaçôes brasileiras em Washington (1908) e em Bruxelas (1921). Uma forma de os países sul-americanos demonstrarem deferência para com seus vizinhos foi nomear para as comemoraçôes dos centenários das independências representantes temporários com o estatuto de embaixadores, como foi o caso de Rui Barbosa na Argentina, em julho de 1916. Por esta causa, a classificação dos grupos de jornalistas como "embaixadas" remetia a missóes especiais e fazia de seus membros mais dignitários do que "simples" diplomatas regulares. Quando, em 1923, Argentina e Brasil elevaram suas respectivas legaçóes à categoria de embaixadas, no modelo europeu, este sentido se perdeu. As embaixadas passaram a ser algo corriqueiro.

Finalmente, três fatores podem ter tornado obsoletas as viagens na década de 1930: o declínio ou desaparecimento de alguns dos principais diários e semanários ativos na promoção das excursóes (Gazeta de Notícias, O País, Caras y Caretas e La Prensa), em um contexto de restrição da liberdade de imprensa; o desenvolvimento do rádio e do cinejornal (que permitia mostrar autoridades e personalidade de um país sem a necessidade de viajar ao exterior e sem a mediação da imprensa) e a articulação de uma política governamental de diplomacia cultural pelos dois países.

\section{Considerações finais}

Entre a última década do século XIX e o segundo quartel do XX, a imprensa carioca e a imprensa portenha criaram e estreitaram laços a partir da prática do envio e recebimento de jornalistas como viajantes cujo estatuto foi definido como o de "embaixadores" informais. Dentre eles, alguns exerceram o papel de mediadores culturais. As "embaixadas" se estruturaram em torno de sociabilidades burguesas, roteiros de visitas, rituais cerimoniosos, ampla cobertura da imprensa e discursos sobre a "amizade". Tratou-se de uma ampla rede que reforçou novos aspectos da autoimagem do jornalismo como expressáo da opiniáo pública e conformou uma diplomacia cultural informal que, embora tenha encontrado apoio - ou ao menos uma benévola aquiescência — nas estruturas governamentais, dela não dependeu.

\footnotetext{
${ }^{58}$ WIGHT, Martin. A política do poder. 2. ed. Brasília e São Paulo: Editora da UnB/Instituto de Pesquisa de Relaçôes Internacionais; Imprensa Oficial do Estado de São Paulo, 2002, p. 107-109.
} 


\section{Fontes documentais}

A Noite, Rio de Janeiro, 1930, 1931.

A Notícia, Rio de Janeiro, 1906, 1914.

A Semana, Rio de Janeiro, 1894.

Caras y Caretas, Buenos Aires, 1899, 1900, 1907, 1915, 1935.

Careta, Rio de Janeiro, 1912, 1913.

Correio da Manhä, Rio de Janeiro, 1910, 1913, 1930, 1931, 1933, 1935.

Correio Paulistano, São Paulo, 1925.

Diário Carioca, Rio de Janeiro, 1929.

Diário de Notícias, Rio de Janeiro, 1888, 1889.

Don Quijote, Buenos Aires, 1888, 1889, 1900.

El Diario, Buenos Aires, 1913, 1915.

El Hogar, Buenos Aires, 1935.

El Tiempo, Buenos Aires, 1913.

Fon-Fon, Rio de Janeiro, 1910, 1913.

Gazeta de Notícias, Rio de Janeiro, 1888, 1890, 1907, 1910, 1914, 1915, 1935.

Ilustração Brasileira, Rio de Janeiro, 1922.

Kosmos, Rio de Janeiro, 1908.

La Nación, Buenos Aires, 1906, 1913.

La Razón, Buenos Aires, 1913.

O Imparcial, Rio de Janeiro, 1920, 1922.

O Jornal, Rio de Janeiro, 1930, 1931.

O Malho, Rio de Janeiro, 1907.

O País, Rio de Janeiro, 1889, 1906, 1907, 1916, 1922, 1926.

P.B.T., Buenos Aires, 1906, 1913, 1914.

Renascença, Rio de Janeiro, 1907.

Revista da Semana, Rio de Janeiro, 1922, 1927, 1935.

Revista Ilustrada, Rio de Janeiro, 1888, 1889.

Tribuna, Buenos Aires, 1915, 1916. 


\section{Referências bibliográficas}

AMANTE, Adriana. Poéticas y políticas del destierro: argentinos en Brasil en la época de Rosas. Buenos Aires: Fondo de Cultura Económica, 2010.

ANSOLABEHERE, Pablo. La vida bohemia en Buenos Aires (1880-1920): lugares, itinerarios y personages. In: BRUNO, Paula (Org.). Sociabilidades e vida intelectual: Buenos Aires, 1860-1930. Bernal: Universidad Nacional de Quilmes, 2014, p. 155-185.

ARARIPE JÚNIOR, Tristão Alencar de. Don García Mérou (perfil literário). In: COUTINHO, Afrânio (Org.). Obra crítica de Araripe Júnior, volume III: 1895-1900. Rio de Janeiro: Ministério da Educaçấo/Casa de Rui Barbosa, 1963, p. 23-61.

ARLT, Roberto. Águas-fortes portenhas seguidas de águas-fortes cariocas. Rio de Janeiro: Iluminuras, 2013.

BAGGIO, Kátia Gerab. Ronald de Carvalho e Toda a América: diplomacia, ensaísmo, poesia e impressôes de viagem na sociabilidade intelectual entre o Brasil e a Hispano-América. In: BEIRED, José Luis Bendicho; CAPELATO, Maria Helena; PRADO, Maria Ligia Coelho (Org.). Intercâmbios politicos e mediaçôes culturais nas Américas. Assis/São Paulo: FCL-AssisUnesp Publicaçôes/Laboratório de Estudos de História das Américas - FFLCH — USP, 2010, p. 193-206.

BARBOSA, Marialva. História cultural da imprensa (Brasil: 1900-2000). Rio de Janeiro: Mauad X, 2007.

BETHELL, Leslie; CARVALHO, José Murilo de; SANDRONI, Cícero (Org.). Joaquim Nabuco: correspondente internacional, 1882-1891. São Paulo: Global, 2013. 2 v.

BRANT, Mario. Viagem a Buenos Aires. Rio de Janeiro: Fundo Editorial AAFBB, 1917.

BRAVO, Alvaro Fernández; MAIZ, Claudio (Org.). Episodios en la formación de redes culturales en América Latina. Buenos Aires: Prometeo, 2009.

BRUNO, Paula (Org.). Visitas culturales en la Argentina, 1898-1936. Buenos Aires: Biblos, 2014.

CANÉ, Miguel. En viaje. Caracas: Fundación Ayacucho, 2005.

CASTRO, Fernando Vale. Pensando um continente: a Revista Americana e a criação de um projeto cultural para a América do Sul. Rio de Janeiro: Mauad/Faperj, 2012.

CAULFIELD, Sueann. Em defesa da honra: moralidade, modernidade e nação no Rio de Janeiro (1918-1940). Campinas: Editora da Unicamp/Cecult, 2000.

DIAS, Artur. Do Rio a Buenos Aires. Rio de Janeiro: Imprensa Nacional, 1901.

DIMAS, Antônio (Org.). Bilac, o jornalista: crônicas, volume 1. São Paulo: Edusp; Editora da Unicamp; Imprensa Oficial, 2006.

DUMONT, Juliette; FLÉCHET, Anaïs. Pelo que é nosso! A diplomacia cultural brasileira no século XX. Revista Brasileira de História, São Paulo, v. 34, n. 67, p. 203-221, jan./jun. 2014. 
GALEANO, Diego. Criminosos viajantes: circulaçôes transnacionais entre Rio de Janeiro e Buenos Aires (1890-1930). Rio de Janeiro: Arquivo Nacional, 2016.

GARCIA, Lúcia. Para uma história da Belle Époque: a coleção de cardápios de Olavo Bilac. Rio de Janeiro: Academia Brasileira de Letras; São Paulo: Imprensa Oficial do Estado de Sáo Paulo, 2011.

GAYOL, Sandra. Sociabilidad en Buenos Aires: hombes, honor y cafés, 1862-1910. Buenos Aires: Ediciones del Siglo, s.d.

GIENOW-HECHT, Jessica C. E. Transmission impossible: American journalism as cultural diplomacy in postwar Germany, 1945-1955. Baton Rouge: Louisiana State University Press, 1999.

. The anomaly of the cold War: cultural diplomacy and civil society since 1850 . In: OSGOOD, Kenneth A.; ETHERIDGE, Brian C. (Org.). The United States and public diplomacy: new directions in cultural and international history. Leiden; Boston: Martinus Nijhoff, 2010.

GONZÁLEZ, Alejandra Pita. La Unión Latino Americana y el boletín Renovación: redes intelectuales y revistas culturales en la década de 1920. Cidade do México: El Colegio de México/Universidad de Colima, 2009.

GROUSSAC, Paul. Del Plata al Niágara. Buenos Aires: La Biblioteca, 1897.

JOBIM, José Luís (Org.). Trocas e transferências culturais; escritores e intelectuais nas Américas. Niterói/Rio de Janeiro: Eduff /De Letras, 2008.

LA PEÑA, Cipriano de. Crónica ilustrada y comentada de las fiestas de confraternidad brasileroargentinas. Buenos Aires: Compañía Sud-americana de Billetes de Banco, 1901.

LIMA, Manuel de Oliveira. Na Argentina (impressóes, 1918-1919). Rio de Janeiro e São Paulo: Weiszflog, 1920.

LINS, Vera; OLIVEIRA, Cláudia de; VELLOSO, Monica Pimenta. O moderno em revista: representaçôes do Rio de Janeiro de 1890 a 1930. Rio de Janeiro: Garamond, 2010.

MÉROU, Martín Garcia. El Brasil Intelectual: impresiones y notas literarias. Buenos Aires: Félix Lajouane, 1900.

NEEDELL, Jeffrey D. Belle Époque tropical: sociedade e cultura de elite no Rio de Janeiro na virada do século. Sáo Paulo: Companhia das Letras, 1993.

OLIVEIRA, Vítor Wagner Neto de. Nas águas do Prata: os trabalhadores da rota fluvial entre Buenos Aires e Corumbá (1910-1930). Campinas: Editora da Unicamp/Cecult, 2009. PICIRILLI, Ricardo. Argentinos en Rio de Janeiro: diplomacia, monarquía, independencia. Buenos Aires: Pleamar, 1969.

PREUSS, Ori. Bridging the island: Brazilians' views of Spanish America and themselves, 1865-1912. Madri: Iberoamericana, 2011. 
. Transnational South America: experiences, ideas and identitities (1860s-1910s). Londres e Nova York: Routledge, 2016.

PRIETO, Adolfo. El discurso criollista en la formación de la Argentina moderna. Buenos Aires: Siglo XXI, 2006.

PRADO, Eduardo. Viagens: América, Oceania e Ásia. São Paulo: Escola Tipográfica Salesiana, 1902.

QUIRÓZ, Pilar González Bernaldo de. Civilidad y politica en los orígenes de la nación argentina: las sociabilidades en Buenos Aires, 1829-1862. Buenos Aires: Fondo de Cultura Económica, 2008.

ROCCA, Pablo. Machado de Assis, escritor do Rio da Prata: duas hipóteses contraditórias. Cadernos de Letras da UFF, Niterói, n. 38, p. 35-49, jan./jul. 2009.

RODRIGUES, João Paulo Coelho de Souza. A geração boêmia: vida literária em romances, memórias e biografias. In: CHALHOUB, Sidney; PEREIRA, Leonardo Affonso de Miranda (Org.). A história contada: capítulos de história social da literatura no Brasil. Rio de Janeiro: Nova Fronteira, 1998, p. 233-264.

. Da revolução à regeneração: crônicas de Machado de Assis e de Olavo Bilac sobre a Argentina. Antiteses, Londrina, v. 6, n. 11, p. 127-148, jan./jun. 2013.

ROGERS, Geraldine. Caras y Caretas: cultura, politica y espetáculo en los inicios del siglo XX argentino. La Plata: Universidad Nacional de La Plata, 2008.

SANTOS, Raquel Paz dos. Relaçôes Brasil-Argentina: a cooperação cultural como instrumento de integração regional. Estudos Históricos, Rio de Janeiro, v. 22, n. 44, p. 355375, jul./dez. 2009.

SARLO, Beatriz. El imperio de los sentimientos: narraciones de circulación periódica en la Argentina. Buenos Aires: Siglo XXI, 2011.

SCHETTINI, Cristiana. Exploração, gênero e circuitos sul-americanos nos processos de expulsão de estrangeiros (1907-1920). Tempo, Rio de Janeiro, v. 16, n. 33, p. 51-73, jul./ dez. 2012.

SILVA, Ana Paula Barcelos Ribeiro da. Diálogos sobre a escrita da história: Brasil e Argentina (1910-1940). Brasília: Fundação Alexandre de Gusmão, 2011.

VERÍSSIMO, José. Homens e cousas estrangeiras (1899-1908). Rio de Janeiro: Topbooks; Academia Brasileira de Letras, 2003.

WIGHT, Martin. A política do poder. 2. ed. Brasília e São Paulo: Editora da UnB/Instituto de Pesquisa de Relaçôes Internacionais; Imprensa Oficial do Estado de São Paulo, 2002.

WILDE, Eduardo. Viajes y observaciones: cartas a "La Prensa", tomo I. Buenos Aires: Martín Biedma, 1892. 


\section{Como citar}

RODRIGUES, João Paulo Coelho de Souza. Embaixadas originais: diplomacia, jornalismo e as relaçóes Argentina-Brasil (1888-1935). Topoi. Revista de História, Rio de Janeiro, v. 18, n. 36, p. 537-562, set./dez. 2017. Disponível em: <www.revistatopoi.org>. 